\title{
Effect of principals' full range of leadership on student learning achievement: a survey of Nepali private schools
}

\author{
Jiban Khadka \\ Faculty of Social Sciences and Education, Nepal Open University, Nepal \\ Email: jiban@nou.edu.np
}

\section{ABSTRACT}

Nepali institutional schools are considered as good performing institutions based on their academic performance. For the school performance, principal's leadership role is pertinent. The objective of this study was to examine three leadership behaviors of Full Range of Leadership: transformational, transactional and laissez-faire leadership in order to find their effect on student learning achievement. The data, using leadership survey questionnaire, were collected from 121 schools of three districts across the country. The findings yielded from the statistical analysis show that the principals exhibit higher level of transformational leadership as compared to transactional leadership and laissez-faire leadership. Both transformational and transactional leadership behaviors were significant predictors of student learning achievement. Relatively, principals' transactional leadership was more effective.

\section{Original Article}

PII: S232247702000008-10

Rec. 07 November, 2020

Acc. 11 December, 2020

Pub. 25 December, 2020

\section{Keywords}

Full Range of Leadership,

Transformational,

Transactional, Laissez-faire,

Student Learning Achievement

\section{INTRODUCTION}

Nepali institutional schools (private schools) are considered as good performing institutions based on their academic performance as compared to community schools (public schools). For example, in the School Education Examination 2019 at the end of tenth grade in Nepali schools, students' Grade Point Average (GPA) above 3.2 was secured by $40.79 \%$ of the students of private schools whereas it was $4.29 \%$ in public schools. Similarly, GPA of below 1.6 was secured by $1.19 \%$ of the students of private schools but it was 14.34\% in public schools (Shrestha, 2019).

For expected or beyond this level of performance, school principal's leadership role is pertinent. School leaders need to motivate their teachers to do more than they originally intended which is possible through the practice of transformational leadership (Bass and Riggio, 2006). In addition to transformational leadership, other two leadership: transactional and laissez-leadership are included in the Full Range of Leadership (FRL) model that can be used to explain a wide range of leadership, and attempts to influence followers on one-to-one level, whole organizations, and even entire cultures
(Northouse, 2013; Bass and Riggio, 2006). However, there is very little known whether the leaders of Nepali private schools practice the FRL in the schools.

Therefore, this study was carried out to address the gap of knowledge, and generalize the findings in similar contexts. The objective of this study was to examine three leadership behaviours of FRL: Transformational, transactional and laissez-faire leadership in relation to the schools' performance, especially, academic performance through the following research questions:

What is the status of three leadership behaviours (transformational, transactional and laissez-faire leadership) of the principals of Nepali private schools?

To what extent does Principals' leadership behaviour affect the student learning achievement?

\section{Leadership Context in Private Schools of Nepal}

In Nepali school education, private schools have remarkable contribution quantitatively and qualitatively. According to Flash Report 2017-2018 published by Department of Education, Nepal, out of 35,601 schools of grade (1-12), 6,566 schools are private which is $18.44 \%$ of the total schools. Similarly, out of $7,391,524$ students of grade (1-12), 1,328,693 students 
are in private schools which is $18 \%$ of the total students. If academic performance- students' test score- is considered for assessing the performance of Nepali private schools, it is remarkably better. The data show the significant contribution of private schools in school education of Nepal. Behind the academic success of the private schools, a study conducted by Thapa (2011) highlighted many reasons such as effective management of physical facilities, family characteristics of a student, parents-teacher meeting, rules of schools, learning environment, and many others. In an exploratory case study done by Shrestha (2007) also defined head teachers as successful leaders of those schools which had wellmaintained facilities and sound academic performance. Despite these all reasons, what about the leadership is in the schools is? Which leadership works best to effectively manage human resourcesteachers- as teachers have significant role on students' academic achievement (Akiri, 2013).

School principal's leadership has a pivotal role to play over the academic success of the school as his/her leadership is a positive correlated factor to other factors, for example, school climate and students' success (Saleem et al., 2012; Nahavandi, 2008). Khanal and Park (2016) state that school principals' role has great impact on students' achievement directly and indirectly as they have influence on school innovation, student behaviour, academic progress, teacher motivation and development, and instructional excellence for the success of a school. Considering the leadership context in private schools of Nepal, in higherperforming schools, the head teachers are found proactive in administration and leadership (Singh and Allison, 2016), however this qualitative based research study has also induced ignorance which leadership the head teachers' practice.

In this concern, some researches like Vanlalhrita (2009), Thapa (2011) and Poudyal (2013) have carried out studies concerning the principals' leadership. The studies have shown that authoritarian or autocratic leadership has been adapted in Nepali private schools; the owner/principal retains all the authority; the employed teacher staff has responsibility without proper authority. From this perspective, these studies indicate that autocratic leadership of the Nepali private schools' principals appear to be a positive determinant of the schools' performance. These findings seem contradictory to several empirical research findings that claim 'autocratic leadership' as an 'ineffective leadership' or show negative correlation between autocratic leadership and school's performance (Nadarasa and Thuraisingam, 2014; Nsubuga, 2008; Singh, 1984). Nonetheless, the findings of the studies on the Nepali private school principals' leadership have not been assessed using standard tools from a representative sample. Further, the studies kept no concern on the extent to which principal's leadership would explain the academic performance. This contradiction and confusion created the need of an investigation on leadership of Nepali private school leaders other than authoritarian or autocratic leadership which can explain the existing performance of the schools.

\section{Full Range of Leadership (FRL): A Wide Range of Implication}

Full Range of Leadership (FRL) model includes three leadership behaviours: Transformational, Transactional and Laissez-faire leadership (Bass and Riggio, 2006). The major concern of this study is to investigate whether Nepali private school principals had been practicing the full range of leadership. The review is focused on FRL model and its relation to organizational performances.

In 'contingency era' (1960s to present) of leadership stated by Nahavandi (2008), transformational leadership as a new approach of leadership was introduced by Burn in 1978, Later, Bass (1985, 1999) developed the TFL model, also called Full Range Leadership (Northouse, 2019). The rationale of the study of this leadership model is that this model focuses more on empirical research studies as compared to other theories, and is found to be more effective (Hariri, 2011). In Nepali institutional school context, how do the principals of the schools inspire their teachers? Do they motivate their teachers? What about individual care for their teachers? Are the teachers given opportunities to show their creativity? Are the principals fair in appreciating the teachers' performance? Are the teachers supported by the school principal? Do they get regular feedback? Are they (teachers) free from the principals' leadership? This study attempts to answer these questions through this FRL leadership model. 
Similarly, this leadership model considers the employees' needs from physiological level to selfactualization. For example, fairness in return to employee's performance, inspiring employees to move beyond their immediate self-interest or expected level of performance are common practices of this model. Every leader display both the transactional and transformational leadership behaviours, but some of them adopt transformational leadership (TFL) more and transactional leadership
(TSL) less or vice versa (Bass, 1999). In practice of the FRL model as described by Hariri (2011), transformational is practiced on one end at higher level, transactional in the middle at moderate level, and laissez-faire leadership (LFL) at the other end at low level. From the understanding of Bass and Riggio (2006), Hariri (2011) and others' research studies, these three-basic leadership behaviours under the FRL model are presented in the following figure 1 in a continuum:

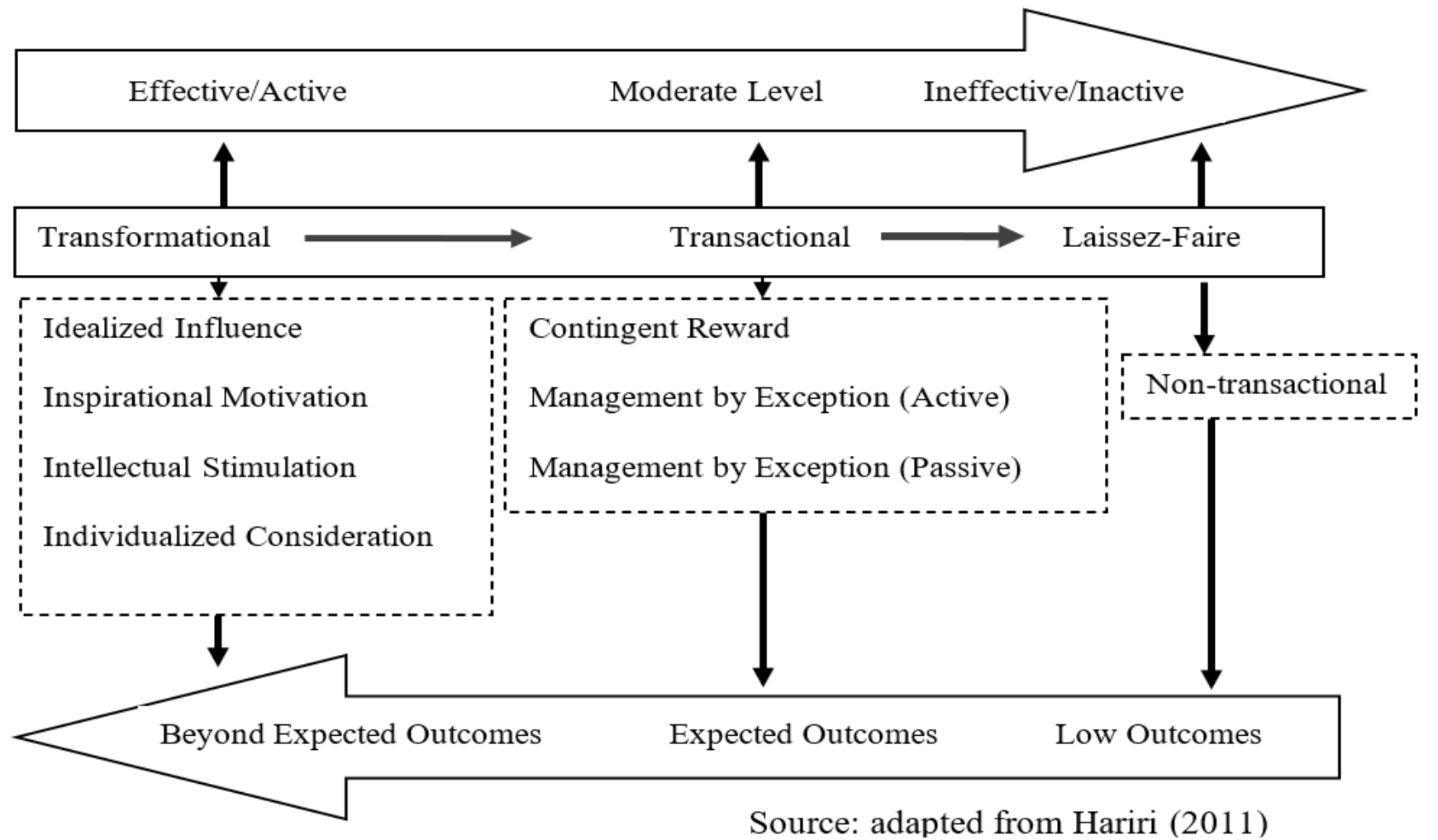

Figure 1. Full Range of Leadership Model: Process and Outcomes

In the practice of FRL model, some concerns arose as to whether Nepali institutional schools' principals practice TFL more and TSL less, or vice versa or equal is a matter of research. What does the laissez-faire leadership of the principals concern with? Some research studies have been carried out to address such issues as well.

As flashed in earlier section, out of three leadership styles, TFL is an active/effective leadership that leads the employees to perform beyond the expected level, and TSL as moderately an active/effective leadership that leads to perform up to the expected level (Hariri, 2011). But, LFL is identified as an inactive/ineffective leadership, and linked to low level of outcomes. Now, it is relevant to contend how these three leadership behaviours are applied in the behaviours and what factors are constituted in three leadership behaviours.

As stated in figure 1, TFL behaviour is composed of different components. However, some of them are similar to each other. Bass and Riggio (2006) state four components of transformational leadership that are charisma or idealized influence, inspirational motivation, intellectual stimulation, and 
individualized consideration (Judge and Piccolo, 2004). The first component 'idealized influence' is defined as role model of a leader, and hence, the followers trust/respect their leaders. The second component is 'inspirational motivation' in which leader provides meaning and challenge to the followers' work. Further, the leader articulates a vision in such a way that followers are inspired and motivated to attend the goal. The third component is 'intellectual stimulation' in which a leader provides opportunity to follower to utilize or use their creativity. Due to this practice, a teamwork can yield the outcome synergistically. The fourth component is 'individualized consideration', that leader understands the followers' need where the followers get high care from leaders. As the leader acts as coach or mentor, the followers individually involve in their work sincerely in the right way.

Similarly, Bass, in 1985, proposed two components of transactional leadership: contingent reward and management by exception. In contingent reward, the followers exchange their effort for specified reward where leaders try to get followers' agreement on the performance standard for the followers' payoff (Northouse, 2013). Further, the leadership behaviour is influenced by management by exception; it involves corrective actions, negative feedback and negative reinforcement against desirable performance. Hater and Bass, in 1988, separated management by exception into two subcomponents. First is management by exception (active) in which a leader takes corrective action during the work before an employee faces any problem and in second sub-component management by exception (passive), a leader ignores providing suggestions during the works (Judge and Piccolo, 2004). In essence, transactional leader believes in bargaining between leader and followers. The leader sets performance standard that the followers have to meet to get rewards. During the course of action, the followers either get corrective actions to meet the standard or they work without support.

Regarding laissez-faire leadership behaviour, a leader allows freedom to group decision without the leader's participation, and due to this reason, it is recommended to be minimized in school context (Adeyemi, 2011). This leadership does not contain any component that collectively contributes to the leadership. The leader delegates almost all power to subordinates and there is no or little presence of authority that leads the organization.

When FRL model is considered theoretically, performance up to the desirable level or even beyond can be expected if the transactional and transformational leadership are adapted together by a leader in an organization. After a review on the FRL model, some questions arise that whether Nepali institutional schools' principals demonstrate three leadership styles: transformational, transactional and laissez-faire leadership in a continuum from effective to ineffective as stated by Bass; whether these leadership behaviours affect the student learning achievement. These are also the matter of study that what personal or social factors influence their leadership. Do the leadership model is significantly different across the principals' demographic characteristics. This study attempted to answer these issues in Nepali private school context.

\section{METHODOLOGY}

The field-based survey within quantitative research approach was employed for this study. The survey of the leadership of private schools' principals as perceived by their teachers was carried out taking a representative sample, determined by Cochran's (1977) formula, using cluster random sampling techniques. Altogether 491 teachers from 121 schools were involved in the survey from three districts located across Eastern, Western and Middle regions of the country. For the student learning achievement, the data of School Education Examination of recent three years were collected from the Office of the Controller of Examination, Bhaktapur.

For the survey of principals' leadership, the leadership survey questionnaire (LSQ) with a list for principals' demographic characteristics was used to assess the teachers' perceptions towards leadership behaviours of their principals. In the process of preparing LSQ, the researcher was permitted to use the questionnaire used by T. C. Obiwuru, A. T. Okwu, V. O. Akpa, and I. A. Nwankwere who assessed the leadership behaviours in their study in 2011 . However, the questionnaire was not sufficient to meet the need of this study as there were some irrelevant items and also missing of the items for measuring laissez-faire 
leadership, the researcher reviewed other literature such as Horn-Turpin (2009), Nsubuga (2008), and Hayward (2005) that would help to prepare a complete set of questionnaire. The questionnaire was prepared in Nepali language version by the process of "translation-back-translation" (Harkness, 2003). It was rater version (teacher version) with five point Likert scale from strongly agree to strongly disagree. Finally, 20 items for transformational, 12 items for transactional and 4 items for laissez-faire leadership were asked to the teachers to rate the leadership exhibited by their principals after ensuring its reliability and validity.

For the quality assurance of the questionnaire, two forms of reliability: stability and internal consistency were established by pilot study. After two rounds of survey of the questionnaire on a sample of 40 participant teachers in pilot study, Spearman's coefficient of correlation for stability in the components of transformational leadership was ranged from .70 to .83 , in the components of transactional leadership, it ranged from .71 to .78 and it was .73 for laissez-faire leadership. The values of Cronbach's alpha for internal consistency were ranged from .70 to .74 in transformational leadership, from .71 to .73 in transactional leadership, and .70 in laissez-faire leadership. This result indicates higher level of reliability on the questionnaire as suggested by Nunnally and Bernstein, an observed correlation is to be at least 0.70 , a lower bound to acceptable reliability (Hertzog, 2008). Subject experts' suggestions and feedback from a group discussion with the teachers were also incorporated to ensure the validity of the questionnaire.

For the statistical methods of data analysis, percentage and frequency were used to analyze the demographic characteristics of the schools' principals. The descriptive statistics: frequency, percentage and ranks were used to examine the level of leadership behaviours of the principals. The percentage of raters on Likert scale items with the range from strongly disagree to strongly agree was the basis of exploring the direction and intensity of Likert scale data analysis. The responses were re-grouped into three categories: Agreement, Neutral and Disagreement for labeling the principals' readership. The binary logistic regression was used to examine the predictive relation of leadership behaviours to the student learning achievement.

\section{RESULTS AND DISCUSSION}

The demographic information of the principals was used to examine the principals' leadership behaviours across their characteristics. From results, the number of female principals was very low as compared to male principals (male $=90 \%$ and female $=10 \%$ ). Majority of the principals were of middle age of 36-45 years, and experience of 5-14 years. The principals with senior age more than 36 years, and long experience with more than five years were leading the institutions. The principals with high level of academic degree had been appointed or the principals acquired higher level of education degree where in the education regulation, minimum bachelor degree is mandatory for the post. Only a few number of principals seemed untrained $(=13.4 \%)$. In overall observation of principals' demographic characteristics, the schools have been led by those principals who are male, senior with long experience, trained with having high level of academic qualification.

\section{Status of Principals' FRL Behaviours}

Average percentages of teachers' responses towards the leadership of their principals were regrouped into three categories: disagreement, undecided and agreement that was used to assess the level of leadership along with their respective components. The findings showed that high number $(=70.5 \%)$ of the teachers agreed that the principals practice transformational leadership. This finding is partially supported by the study carried by Pokhrel (2015). His study showed that transformational leadership skills were not displayed by the Nepali institutional principals. However, in quantitative analysis, he revealed that most of the teachers rated their principals that they develop shared culture in their schools, frequently trust building, act with integrity, inspire others, encourage innovative thinking, coach people. From this point of view, the principals of the schools fairly practice transformational leadership in the schools.

Considering the transactional leadership, more than half $(=60.3 \%)$ of teachers agreed on rating the 
principals as exhibiting transactional leadership, and still one fourth of the teachers rated their principals as adopting laissez-faire leadership. $60.5 \%$ of the teachers disagreed that their principals exhibit laissez-faire leadership. Then, they display either transformational or transactional leadership behaviours. Only $20.9 \%$ and $8.6 \%$ of the respondent teachers disagreed that the principals display transactional and transformational leadership respectively. In the current literature on these two leadership behaviours: transactional and laissez-faire in Nepali schools context are the issues of little concern. However, this finding is similar in some extent to a case study of Poudyal (2013) that shows the principals practice transactional leadership as authoritative leadership in the schools. In overall observation across three leadership behaviours, this finding supports what Bass (2000) says that transactional leadership is effective up to the exchange level and transformational leadership beyond it. As perceived by the teachers, two leadership behaviours of the principals: nontransactional (laissez-faire) and management by exception (passive) were rated in the opposite end of the continuum of other leadership styles (transformational and transactional leadership).

Non-parametric tests (Mann Whitney U Test for two sub-groups and Kruskal Wallis H Test for more than two sub-groups of principals) showed that both transformational and transactional leadership across the demographic characteristics of Principals: Gender, age, qualification, experience and training status was not significantly difference at $5 \%$ level of significance as $\mathrm{p}$-value was less than the significant value.

In the case of laissez-faire leadership, it was significantly across the different age group of teachers. Bonferroni post hoc test was used to identify the two groups in which the significant difference would exist. The test revealed that the principals with the experience years of 15-20 years was significantly different from other three experience groups of principals. This result showed that the principals who were from the age group of 15-20 years were rated at higher level in the practice of laissez-faire leadership. This is left for future researches that why the teachers of this group demonstrate the laissez-faire leadership.

Although the results were statistically insignificant, some interesting results are found from the observation of the pattern of rank values yielded from the non-parametric tests. For examples, female principals were rated at higher rank in both transformational and transactional leadership as compared to male principals. The principals were found practicing transactional leadership more as their age and experience increase. It is similar for transformational leadership in the case of their experience. Principals with the qualification of above bachelor degree or training received were ranked at higher level of both transformational and transactional leadership in comparison to the principals with qualification of bachelor degree or who had not received training.

Regarding the leadership of the principals and their gender, the findings correspond to the findings of Shrestha (2007), Al Noor et al. (2011), Grunes (2011), Craven and Kao (2006) and Ibukun et al. (2012) that female leaders exhibits transformational leadership behaviours. However, it contradicts the findings of Mohammed et al. (2012), and Mandell and Pherwani (2003). In regard with the leadership behaviours and the age of principals, the result did not show any significant difference. It is consistent with the study of Barbuto et al. (2007) and partially supports to Craven and Kao (2006). In contrast, Ibukun et al. (2012) contend that the principals with higher age significantly performed better than younger principals. Regarding principals' leadership styles and their experience, it was also not statistically different. It supports the findings of Craven and Kao (2006) but contradicts to the finding of Ibukun et al. (2012) that the more experienced principals were better performers. The finding of the study also supports the finding of Craven and Kao (2006) and Mohammed et al. (2012) that the leadership behaviours of the principals do not significantly differ from the qualification of principals. These evidences showed that there was no uniformity in the practice of leadership behaviours based on their demographic characteristics. Rather, leaders practice their leadership behaviours as per the situation rather than their demographic characteristics.

Effect of Principals' FRL Behaviour on Student Learning Achievement

Binary logistic regression model was used to investigate the effects of principal's leadership on the 
student learning achievement. The model considered the assumptions of multicollinearity, dependent variable as dichotomous and minimum number of 50 in each group of independent variable maximum likelihood coefficients. The statistical results are as follows:

Table 1. Model Summary

\begin{tabular}{llll}
\hline \multirow{2}{*}{ Step } & $\begin{array}{l}-2 \text { Log } \\
\text { likelihood }\end{array}$ & $\begin{array}{l}\text { Cox \& Snell } \\
\text { R Square }\end{array}$ & $\begin{array}{l}\text { Nagelkerke } \\
\text { R Square }\end{array}$ \\
\hline 1 & 243.187 & .107 & .188 \\
\hline
\end{tabular}

From table 1, the independent variables: three leadership behaviours and demographic characteristics reduced the -2 Log Likelihood statistics to 243.187. The table shows that the value of Nagelkerke R Square was .188. This did not indicate very strong predictability power of the logistic regression model that mean approximately 19\% percentage of the variation in dependent variable: student learning achievement had been explained by the considered independent variables (covariates).

Table 2. Variables in the Equation

\begin{tabular}{|c|c|c|c|c|c|c|}
\hline Variables & B & S.E. & Wald & df & Sig. & $\operatorname{Exp}(B)$ \\
\hline $\begin{array}{l}\text { Transformational leadership }\left(\mathrm{x}_{1}\right) \text { : } \\
\text { (High level of TFL with reference to Low level) }\end{array}$ & .958 & .406 & 5.584 & 1 & .018 & 2.607 \\
\hline $\begin{array}{l}\text { Transactional leadership }\left(\mathrm{x}_{2}\right) \text { : } \\
\text { (High level of TSL with reference to Low level) }\end{array}$ & 1.275 & .395 & 10.435 & 1 & .001 & 3.578 \\
\hline $\begin{array}{l}\text { Laissez-faire leadership }\left(\mathrm{x}_{3}\right) \text { : } \\
\text { (High level of LFL with reference to Low level) }\end{array}$ & .653 & .432 & 2.282 & 1 & .131 & 1.922 \\
\hline $\begin{array}{l}\text { Gender }\left(\mathrm{x}_{4}\right): \\
\text { (Female with reference to male) }\end{array}$ & .543 & .666 & .664 & 1 & .415 & 1.720 \\
\hline Age $\left(\mathrm{x}_{5}\right)$ : (Age with reference to the age up to 35 years) & -.360 & .421 & .731 & 1 & .393 & .698 \\
\hline Experience $\left(\mathrm{x}_{6}\right)$ : (Experience with reference to the experience below 15 years) & .305 & .409 & .556 & 1 & .456 & 1.357 \\
\hline $\begin{array}{l}\text { Qualification }\left(\mathrm{x}_{7}\right) \text { : (Qualification above Bachelor degree with reference to } \\
\text { Bachelor) }\end{array}$ & .534 & .443 & 1.450 & 1 & .229 & 1.706 \\
\hline $\begin{array}{l}\text { Training Status }\left(\mathrm{x}_{8}\right) \text { : (Training received with reference to the training not } \\
\text { received) }\end{array}$ & -.802 & .536 & 2.236 & 1 & .135 & .448 \\
\hline Constant & .335 & .749 & .200 & 1 & .655 & 1.398 \\
\hline
\end{tabular}

From the table 2, in aggregate, the logistic regression equation was:

$\operatorname{Logit}(\mathrm{P})=1.398+2.607 \mathrm{x}_{1}+3.578 \mathrm{x}_{2}$

The results showed that the covariates: transformational and transactional leadership behaviours positively and significantly explained the student learning achievement. Demographic characteristics of the principals (gender, age, experience, qualification, and training) and one of the leadership behavior (Laissez-faire leadership) were not found significant predictors to explain their student learning achievement. The following statistical results are important to analyze effect of FRL on student learning achievement:

[Wald' s $\chi^{2}=5.584,10.435$,

$P=.018, .001<.05$,

odds ratio $=\exp (B)=2.607,3.578]$
The results show that the principals with high level of both TFL and TSL were more likely to have their student learning achievement better. Compared to those principals with lower level of TFL and TSL, the principals with higher level of TFL and TSL were both about three to four (= 2.607 and 3.578) times more likely to have their student learning achievement respectively. The findings of this study are supported to several researches as follows:

Regarding the effect of TFL on student learning achievement, the finding of this study is in line with the many international research studies that showed the positive effects of the TFL on various aspects of educational and other types of organizations. For example, the studies of Grunes (2011), Ojokuku et al. (2012), Cemaloglu et al. (2012), Miao et al. (2012) and many others showed positive influence of TFL on the outcomes such as satisfaction, motivation, and 
performance of the follower. But, in the case of transactional leadership, this finding supports only a few number of research studies. For example, Cemaloglu et al. (2012) found significant relationships between TSL style and organizational performances. Nevertheless, this study contradicted to many researchers such as Shahhosseini et al. (2013), Ying et al. (2012), and Fernandes and Awamleh (2004). Their studies showed that TSL as a negative and (in)significant influencing factor on the followers and organizations' performance. Regarding the effect of Laissez-faire leadership, the finding of this study partially agreed with some past studies. For example, Nsubuga's (2008) study showed very low level of correlation of LFL behaviour with schools' performance. Unlikely to many research findings such as Hariri (2011), LFL behavior of the principals did not seem to be a negative predictor of the schools' performance.

In conclusion, two leadership behaviours: TFL and TSL are reveled significantly effective which supports the review of Khanal and Park (2016). From the result of this study as stated above, Full Range of Leadership, and the student learning achievement are functionally related as $A=f(L)+\varepsilon_{1}$, where A: student learning achievement, L: two leadership behaviours (TFL and TSL), $\varepsilon$ : errors, some other unidentified variables $\left(\varepsilon_{1}\right)$ which this model did not identified.

\section{CONCLUSION}

In Nepali institutional schools, the principals, as perceived by their teachers, practice transformational and transactional leadership behaviours. They exhibit idealized influencing behaviour, inspirational motivation role as well as individualized consideration. They practice transactional leadership behavioura less as compared to transformational leadership however this transactional leadership is more effective to explain student learning achievement. As transactional leader, they manage contingent reward and practice active management by exception. These two variables (transformational and transactional leadership) collectively explain the effectiveness of the principals' leadership in Nepali institutional schools. In relation with the performance of Nepali institutional school context, this study has established an empirical relation that higher the transformational and transactional leadership the principals exhibit, greater is the effectiveness of the leadership on student learning achievement. This idea can lead us to conclude that leadership performance in schools can be enhanced by developing transformational and transactional leadership in Nepali private schools or in similar context, particularly, public schools.

\section{Competing interests}

The authors declare that they have no competing interests.

\section{REFERENCES}

Adeyemi, T.O. (2010). Principals leadership styles and teachers job performance in senior secondary schools in Ondo State, Nigeria. International Journal of Educational Administration and Policy Studies, 2(6): 8391. Google Scholar, https://doi.org/10.5897/IJEAPS10.019

Akiri, A.A. (2013). Effects of teachers' effectiveness on students' academic performance in public secondary schools; Delta State-Nigeria. Journal of Educational and social Research. Sep 3:3(3):105-. Google Scholar

Barbuto, J.E., Fritz, S.M., Matkin, G.S., Marx, D.B. (2007). Effects of gender, education, and age upon leaders' use of influence tactics and full range leadership behaviors. Sex Roles. Jan 1; 56(1-2):71-83. Google Scholar

Bass, B.M. and Riggio, R.E. (2006). Transformational leadership (2nd ed.). London: Lawrence Erlbaum Associates.

Bass, B.M. (1999). Two decades of research and development in transformational leadership. European journal of work and organizational psychology. 8(1):9-32. Google Scholar, https://doi.org/10.1080/135943299398410

Bass, B.M. (2000). The future of leadership in learning organizations. Journal of leadership studies. 7(3):18-40. Google Scholar https://doi.org/10.1177/107179190000700302

Cemaloglu, N., Sezgin, F., Kılınç, A.Ç. (2012). Examining the relationships between school principals' transformational and transactional leadership styles and teachers' organizational commitment. The Online Journal of New Horizons in Education. 2(2):53-64. Google Scholar

Cochran, W.G. (1977). Sampling techniques (3rd ed.). New York: John Wiley and Sons.

Fernandes, C, Awamleh, R. (2004). The impact of transformational and transactional leadership styles on employees satisfaction and performance: an empirical test in a multicultural environment. International Business \& Economics Research Journal (IBER). 3(8). Google Scholar, https://doi.org/10.19030/iber.v3i8.3715 
Grunes, P. (2011). An examination of the relationship between emotional intelligence, leadership style and perceived leadership outcomes in Australian educational institutions (Doctoral dissertation, Queensland University of Technology). Google Scholar

Hariri, H. (2011). Leadership styles, decision-making styles, and teacher job satisfaction: an Indonesian school context (Doctoral dissertation, James Cook University).. Google Scholar

Harkness, J. (2003). Questionnaire translation. In J. Harkness, F. Van de Vijer \& P. Moher (Eds.), Cross cultural survey methods (pp. 35-56). London: John Wiley \& Sons.

Hayward, B.A. (2006). Relationship between employee performance, leadership and emotional intelligence in a South African parastatal organisation(Doctoral dissertation, Rhodes University). Google Scholar

Hertzog, M.A. (2008). Considerations in determining sample size for pilot studies. Research in nursing \& health. Apr;31(2):180-91. Google https://doi.org/10.1002/nur.20247

Horn-Turpin, F.D. (2009). A study examining the effects of transformational leadership behaviors on the factors of teaching efficacy, job satisfaction and organizational commitment as perceived by special education teachers (Doctoral dissertation, Virginia Tech). Google $\underline{\text { Scholar }}$

Ibukun, W.O., Oyewole, B.K., Abe, T.O. (2011). Personality characteristics and principal leadership effectiveness in Ekiti State, Nigeria. International Journal of Leadership Studies; 6(2):247-62. Google Scholar

Judge, T.A., Piccolo, R.F. (2004). Transformational and transactional leadership: a meta-analytic test of their relative validity. Journal of applied psychology. 89(5):755. Google Scholar

Craven, A.E., Kao, T.Y. (2006). The relationship between leadership style \& demographic characteristics of Taiwanese executives. International Business \& Economics Research Journal (IBER). 5(2). Google Scholar, https://doi.org/10.19030/iber.v5i2.3456

Khanal, J., Park, S.H. (2016). Impact of school principal leadership. Journal of American Academic Research; 4(6):1-9. Google Scholar

Mandell, B., Pherwani, S. (2003). Relationship between emotional intelligence and transformational leadership style: A gender comparison. Journal of business and psychology. 17(3):387-404. Google Scholar

Miao, Q., Newman, A., Lamb, P. (2012). Transformational leadership and the work outcomes of Chinese migrant workers: The mediating effects of identification with leader. Leadership. 8(4): 377-95. Google Scholar, https://doi.org/10.1177/1742715012444055

Mohammed, K.A., Othman, J., D'Silva, J.L. (2012). Social demographic factors that influence transformational leadership styles among top management in selected organizations in Malaysia. Asian Social Science. 8(13):51. Google Scholar

Nadarasa, T., Thuraisingam, R. (2014). The influence of principals' leadership styles on school teachers' job satisfaction-study of secondary school in Jaffna district. International Journal of Scientific and Research Publications. 4(1):1-7. Google Scholar

Nahavandi, A. (2008). The art and science of leadership (5th ed.). New York, NY: Prentice Hall.

Al Noor M, Uddin I, Shamaly SS. (2011). Leadership style and emotional intelligence: A gender comparison. European Journal of Business and Management. (3). Google Scholar

Northouse, P. G. (2013). Leadership: Theory and practice (6th ed.). New Delhi: Sage.

Northouse, P. G. (2019). Leadership: Theory and practice (6th ed.). New Delhi: Sage.

Nsubuga YK. (2008). Analysis of leadership styles and school performance of secondary schools in Uganda (Doctoral dissertation, Nelson Mandela Metropolitan University). Google Scholar

Obiwuru, T.C., Okwu, A.T., Akpa, V.O., Nwankwere, I.A. (2011). Effects of leadership style on organizational performance: A survey of selected small scale enterprises in Ikosi-Ketu council development area of Lagos State, Nigeria. Australian journal of business and management research. 1(7):100. Google Scholar

Ojokuku, R.M., Odetayo, T.A., Sajuyigbe, AS. (2012). Impact of leadership style on organizational performance: a case study of Nigerian banks. American journal of business and management; 1(4):202-7. Google Scholar, https://doi.org/10.11634/216796061706212

Pokhrel, B. (2015). Principals for school change: A study of institutional schools of Nepal (Unpublished doctoral dissertation). Kathmandu University School of Education, Lalitpur, Nepal.

Poudyal C. (2013). Private schooling and Fayol's principles of management: A case from Nepal. Journal of Education and Research. 3(1):6-23. DOI: http://dx.doi.org/10.3126/jer.v3i0.7849 Google Scholar

Saleem, F., Naseem, Z., Ibrahim, K., Hussain, A., Azeem, M. (2012). Determinants of School Effectiveness: A study at Punjab level. International journal of humanities and social science. 2(14):242-51. Google Scholar

Shahhosseini, M., Silong, A.D., Ismaill, I.A. (2013). Relationship between transactional, transformational leadership styles, emotional intelligence and job performance. Researchers World. 4(1):15. Google Scholar

Shrestha, J.B. (2007). Leadership effectiveness at schools. A study of multiple requisites exhibited by successful headteachers in Nepal (Unpublished doctoral dissertation). Tribhuvan University, Nepal. 
Shrestha, M. (2019). Gradinglai prayogatmakko teko. National Weekly Shikshapatra, issue no. 10, year 1, 2019. Kathmandu

Singh, I. (1984). The effects of the headmaster's leadership on teacher job satisfaction and morale as perceived by the teachers in Nepal (Unpublished doctoral dissertation). Columbia University, USA.

Singh, S.B., Allison, D.J. (2016). School Leadership Practices of Headteachers in Kathmandu. International Studies in Educational Administration (Commonwealth Council for Educational Administration \& Management (CCEAM)). 44(3). Google Scholar
Thapa, A. (2013). Does private school competition improve public school performance? The case of Nepal. International Journal of Educational Development. 33(4):358-66. Google Scholar, https://doi.org/10.1016/j.ijedudev.2012.07.004

Vanlalhrita, J. M. (2009). Influence of leadership styles of principals on school climate and commitment of teachers (Unpublished MPhil. dissertation). Kathmandu University School of Education, Lalitpur, Nepal.

Ying, C.Y., Ken, S., Ting, T. (2012). Emotional intelligence and transformational leadership outcomes: insights from a Malaysian perspective. World Journal of Social Sciences. 2(2):151-60. Google Scholar 